\title{
A Long Journey Ahead: Long Non-coding RNAs in Bacterial Infections
}

\author{
Jennifer zur Bruegge *, Ralf Einspanier and Soroush Sharbati \\ Department of Veterinary Medicine, Institute of Veterinary Biochemistry, Freie Universität Berlin, Berlin, Germany
}

Bacterial pathogens have coevolved with their hosts and acquired strategies to circumvent defense mechanisms of host cells. It was shown that bacteria interfere with the expression of mammalian microRNAs to modify immune signaling, autophagy, or the apoptotic machinery. Recently, a new class of regulatory RNAs, long non-coding RNAs (IncRNAs), was reported to have a pivotal role in the regulation of eukaryotic gene expression. A growing body of literature reports on specific involvement of IncRNAs in the host cell response toward bacterial infections. This mini review summarizes recent data that focuses on IncRNA function in host cells during bacterial infection and provides a perspective where future research in this regard may be going.

Keywords: long non-coding RNAs (IncRNAs), bacterial infection, epigenetic regulation of gene expression, host-pathogen interaction, immunity

\section{INTRODUCTION}

OPEN ACCESS

Edited by:

Rey Carabeo,

Washington State University, USA

Reviewed by:

Gucheng Zeng,

Sun Yat-sen University, China

Alice Lebreton,

École Normale Supérieure, France

*Correspondence:

Jennifer zur Bruegge

jennifer.zur.bruegge@fu-berlin.de

Received: 15 February 2017 Accepted: 13 March 2017 Published: 28 March 2017

Citation:

zur Bruegge J, Einspanier $R$ and Sharbati S (2017) A Long Journey Ahead: Long Non-coding RNAs in

Bacterial Infections.

Front. Cell. Infect. Microbiol. 7:95. doi: 10.3389/fcimb.2017.00095
Interkingdom communication between hosts and microbes is one of the propelling aspects in mammalian evolution. Mucosal surfaces provide an extensive area, which is in direct contact with bacteria, fungi and viruses. Bilateral communication of the mucosal tissue with microbiota is essential for colonization, homeostasis, and development. On the other hand, bacterial pathogens have coevolved with their hosts and have acquired mechanisms to defeat mucosal barrier, invade and hijack phagocytes, and interfere with phagosome biogenesis or apoptotic pathways to manifest infection (Pieters, 2008; Rocco and Irani, 2011; Sharbati et al., 2011). Many bacterial pathogens such as mycobacteria, listeriae, and salmonellae can invade host cells and replicate inside.

Intracellular bacterial pathogens have been shown to interfere with expression of small noncoding, regulatory RNAs like microRNAs (miRNA) affecting host cell response signaling pathways such as apoptosis and autophagy (Rodriguez et al., 2007; Schulte et al., 2011; Sharbati et al., 2011, 2012; Hoeke et al., 2013; Pawar et al., 2016b; zur Bruegge et al., 2016). While the role of miRNAs in bacterial infections has been extensively studied and excellently reviewed in previous years (Eulalio et al., 2012; Das et al., 2016; Kim et al., 2017), we are beginning to realize the pivotal role of another class of regulatory RNA molecules, which are collectively referred to as long noncoding RNAs (lncRNAs). Next-Generation RNA sequencing (RNAseq) studies have examined that the majority of the mammalian genome is transcribed but very little of it has the ability to encode for proteins (Birney et al., 2007). IncRNAs are distinguished from other non-coding RNAs primarily based on their size of larger than $200 \mathrm{nt}$. Their numbers are estimated to reach those of protein coding genes but they are generally shorter, have fewer exons and possess low evolutionary conservation (Bertone et al., 2004; Heward and Lindsay, 2014). Furthermore, they have lower level of cellular concentration than protein-coding transcripts but have a higher degree of tissue specificity (Pang et al., 2006; Marques and Ponting, 2009). IncRNAs are frequently localized in 
the nucleus functioning both in cis (at the site of their transcription) and in trans (at the sites on other chromosomes), which points to potential functions as interfaces with the epigenetic machinery, chromatin organization, and regulation of gene expression. lncRNAs function e.g., as protein scaffolds, activators, or inhibitors of transcription, antisense RNA or miRNA sponges, respectively (Cech and Steitz, 2014; Rinn, 2014). The latter has been reported recently as a novel mode of action of lncRNAs, where they act as competing endogenous RNA (ceRNA). This suggests the existence of a network of lncRNAs, miRNAs, and mRNAs crosstalking based on mutual miRNA response elements (MRE; Salmena et al., 2011; Hanisch et al., 2017). There are many subclasses of lncRNAs, classified e.g., based on their length and location such as long intergenic RNAs (lincRNAs) or based on their association with annotated protein coding genes such as natural antisense transcripts (NATs; St Laurent et al., 2015). A growing body of literature reports on specific lncRNA involvement in host cell response to bacterial infections. This mini review is intended to summarize very recent data on lncRNA function in bacterial infections. We aim at combining these pioneering data with relevant cellular signaling pathways that are manipulated by bacterial pathogens to provide a perspective where further research in this regard may be going.

\section{EXPLORING IncRNA FUNCTION THROUGH THE ANALYSIS OF NEIGHBORING CODING GENES}

The fact that lncRNAs are prominently involved in the response of different host cells to various bacterial agents such as Mycobacterium (M.) spp., Salmonella (S.) Typhimurium, Escherichia coli, Listeria (L.) monocytogenes, Helicobacter pylori, and Campylobacter (C.) concisus as well as TLR ligands has been recently demonstrated in several studies but the functions of these lncRNAs remain to be elucidated (Ilott et al., 2014; Yi et al., 2014; Yang et al., 2015; Zhu et al., 2015; Yang R. et al., 2016; Westermann et al., 2016).

lncRNAs have been reported to regulate the expression of neighboring protein-coding genes through a locus control process (Wang and Chang, 2011; Wang et al., 2011). Therefore, functions may be speculated from their locus and adjacent protein coding genes. According to this assumption, genes related to immune functions are most likely influenced by lncRNAs induced by bacterial pathogens. For example, Tolllike-receptor (TLR) 4 activation of primary human monocytes stimulated with LPS led to differential expression of a comprehensive set of IncRNAs. Two hundred and twentyone out of nine hundred and eighty nine lncRNAs showed LPS-induced differences in expression levels (Ilott et al., 2014). Interestingly, differentially expressed lncRNAs were closely located to differentially expressed inflammatory genes. Another group investigated publicly available microarray data of LPS stimulated mouse macrophages and identified several lncRNAs to be differentially regulated upon stimulation. They found a correlation in the expression of many lncRNAs and neighboring protein-coding genes, for example NFKB2 or Rel, both involved in NFKB signaling (Mao et al., 2015).

In THP-1 macrophages infected with C. concisus 333 long intergenic RNAs (lincRNAs, a subclass of lncRNAs) were differentially expressed compared to uninfected cells (Kaakoush et al., 2015). Among these, eight were exclusively expressed in infected cells. The functions of these eight lincRNAs are unknown but their adjacent protein coding genes were shown to be involved in the regulation of immune responses. For example, in $C$. concisus infected cells the protein coding gene TNFAIP3 (which was upregulated 25.7-fold by the infection) adjacent to regulated lncRNAs was shown to inhibit TNFand IL1-induced NFKB gene expression (Song et al., 1996). It was shown that TNFAIP3 is induced by TNF and IL-1 and might therefore be involved in the regulation of NFKB dependent genes in diverse bacterial infections. Consequently, the IncRNA adjacent to TNFAIP3 induced by C. concisus might be a $\mathrm{NF} \kappa \mathrm{B}$ regulator influenced by several pathogens known to affect $\mathrm{NF \kappa B}$ signaling. In accordance with this, Ma et al. recently demonstrated that there is a lncRNA (lincRNA-Tnfaip3) located at mouse chromosome 10 proximal to TNFAIP 3 which acts as an early response gene controlled by NFKB signaling in LPS stimulated mouse macrophages (Ma et al., 2016). LincRNATnfaip3 seems to assemble a NFKB/Hmgb1/lincRNA-Tnfaip3complex in response to LPS which leads to epigenetic chromatin remodeling and transactivation of inflammatory genes in mouse macrophages.

Speculating on lncRNA function based on their locus and function of neighboring protein coding genes might therefore be useful to predict potential lncRNA mechanisms and identify possible targets to discover gene regulatory functions during infection. However, only a fraction of reported lncRNAs involved in the immune response toward bacterial infection were validated in terms of mechanisms and mode of action. Directed approaches as described below and suitable knock-out models are needed to predict and functionally explore suchlike lncRNAs in host organisms infected with bacterial pathogens.

\section{FUNCTIONAL AND MECHANISTIC STUDIES}

A wealth of research projects have been carried out to elucidate the mechanisms how small ncRNAs, especially miRNAs, interact with their target molecules and post-transcriptionally inhibit gene function during bacterial infections. However, in case of lncRNAs the current knowledge is restricted to a handful of studies that investigated the functional role of certain lncRNAs during pathogen challenge or stimulation with pathogen associated molecular patterns (PAMPs). Some lncRNAs mediate their function through similar mechanisms e.g., promoting changes in chromatin methylation states or interacting with heterogenous ribonucleoproteins (hnRNPs). For other lncRNAs the function could be associated to a specific pathway, however, the molecular mode of action by which the function is mediated remains to be explored. A summary of lncRNAs that were 
validated in terms of function and/or mode of action is listed in Table 1.

\section{IncRNA-Mediated Modulation of Chromatin Methylation States}

Several lncRNAs were shown to control transcription of mRNAs by turning the methylation state of their target genes to an active or suppressive condition.

For example, the Polycomp Repressive Complex 2 (PCR2) exhibits methyltransferase activity through its subunit EZH2 and leads to trimethylation of a lysine residue at position 27 in the protein histone $\mathrm{H} 3$ ( $\mathrm{H} 3 \mathrm{~K} 27 \mathrm{me} 3)$. $\mathrm{H} 3 \mathrm{~K} 27 \mathrm{me} 3$ is a marker for transcriptional repression. PCR2 consists of several subunits. Two of them, mentioned EZH2 (exhibits methyltransferase activity) and SUZ12 (a zinc-finger protein) have been reported to interact with lncRNAs to inhibit expression of target genes by repressing chromatin at the respective promotors (Khalil et al., 2009).

TNF- $\alpha$ seems to be a prominent target regulated by this mechanism during bacterial infections. It was shown that the lncRNA-CD244 which is upregulated by the T-cell inhibitory molecule CD244 in $M$. tuberculosis infection acts as an epigenetic inhibitor of TNF- $\alpha$ and INF- $\gamma$ expression. The authors were able to show that IncRNA-CD244 directly interacts with the PCR2 subunit EZH2 which leads to trimethylation of H3K27 and a more repressive chromatin state at the INF- $\gamma$ or TNF- $\alpha$ loci
(Wang et al., 2015). A similar mechanism in terms of lncRNAmediated control of TNF expression has been reported through bidirectional lncRNAs upstream of the TNF gene locus (Shi et al., 2014). The authors were able to show that these unnamed lncRNAs bind LRRFIP1 (a repressor of TNF) and chromatin. Furthermore, the data suggests a scaffolding function for these lncRNAs by which the 2 subunits of the PCR2 complex (EZH2 and SUZ12) and LRRFIP1 are assembled to the TNF region to maintain a repressed chromatin state at the TNF promotor forming an inhibitory complex.

TNF- $\alpha$ plays a major role in the host response to control M. tuberculosis infection. To promote infection and ensure persistence and replication in the host cell, M. tuberculosis is known to successfully inhibit TNF- $\alpha$ production via diverse mechanisms including modulation of the miRNA host response (Reed et al., 2004; Kurtz et al., 2006; Singh et al., 2013). Depending on the cellular context, TNF can either induce apoptosis or NFאB-mediated survival. Many bacterial pathogens such as S. Typhimurium or Yersinia enterocolitica are known to interfere with TNF signaling to promote pathogenicity (Rahman and McFadden, 2006). Modulation of TNF expression through lncRNAs is a new reported mechanism which might possibly be employed by other pathogens interfering with TNF levels to establish infection.

Another lncRNA affecting the trimethylation state of $\mathrm{H} 3 \mathrm{~K} 27$ is lnc-IL7R. It was highly induced in THP-1 cells as well as PBMCs

TABLE 1 | Validated functions and mechanisms of IncRNAs expressed in host cells during bacterial infection or stimulation with bacterial compounds.

\begin{tabular}{|c|c|c|c|c|c|}
\hline IncRNA & Host organism & $\begin{array}{l}\text { Pathogen/microbial } \\
\text { component }\end{array}$ & Function & Mechanism & References \\
\hline LincRNA-Tnfaip3 & Mouse macrophages & LPS & $\begin{array}{l}\text { Activation and repression } \\
\text { of distinct classes of } \\
\text { inflammatory genes }\end{array}$ & $\begin{array}{l}\text { Assembles a NFkB } \\
\text { /Hmgb1/lincRNA-Tnfaip3 } \\
\text { complex which modulates } \\
\text { Hmgb1-associated } \\
\text { histone modifications }\end{array}$ & Ma et al., 2016 \\
\hline IncRNA- CD244 & CD8+ T cells & M. tuberculosis & $\begin{array}{l}\text { Inhibition of TNF- } \alpha \text { and } \\
\text { INF- } \gamma \text { expression }\end{array}$ & Interaction with PCR2 & Wang et al., 2015 \\
\hline Unnamed IncRNAs & THP-1 cells & LPS & $\begin{array}{l}\text { Regulates TNF- } \alpha \\
\text { expression }\end{array}$ & $\begin{array}{l}\text { Interaction with PCR2 } \\
\text { subunit EZH2, SUZ12 and } \\
\text { LRRFIP1 }\end{array}$ & Shi et al., 2014 \\
\hline IncRNA-IL7R & THP-1 & LPS, TLR2-ligand & $\begin{array}{l}\text { Reduces the expression of } \\
\text { LPS induced inflammatory } \\
\text { mediators such as } \\
\text { E-selectin and VCAM-1 }\end{array}$ & $\begin{array}{l}\text { Increases trimethylation of } \\
\text { H3K27 }\end{array}$ & Cui et al., 2014 \\
\hline $\mathrm{NeST}$ & Mice & $\begin{array}{l}\text { Salmonella (and } \\
\text { Theiler's virus) }\end{array}$ & INF- $\gamma$ upregulation & Interaction with WDR5 & Gomez et al., 2013 \\
\hline \multirow[t]{2}{*}{ lincRNA- Cox2 } & Mouse macrophages & $\begin{array}{l}\text { LPS, TLR2-ligand, L. } \\
\text { monocytogenes }\end{array}$ & $\begin{array}{l}\text { Regulates the expression } \\
\text { of immune related genes }\end{array}$ & Interaction with hnRNP & Carpenter et al., 2013 \\
\hline & $\begin{array}{l}\text { Mouse bone marrow derived } \\
\text { dendritic cells }\end{array}$ & LPS & & & Guttman et al., 2009 \\
\hline THRIL & THP-1 & TLR2-ligand & $\begin{array}{l}\text { Regulates TNF- } \alpha \\
\text { expression }\end{array}$ & Interaction with hnRNP & Li et al., 2014 \\
\hline lincRNA- EPS & $\begin{array}{l}\text { Macrophages and dendritic } \\
\text { cells }\end{array}$ & $\begin{array}{l}\text { L. monocytogenes, } \\
\text { TLR2-, TLR3-, } \\
\text { TLR4-ligands }\end{array}$ & $\begin{array}{l}\text { Controls immune related } \\
\text { genes }\end{array}$ & Interaction with hnRNP & Atianand et al., 2016 \\
\hline IncRNA AS-IL1 $\alpha$ & Mouse macrophages & $\begin{array}{l}\text { L. monocytogenes, } \\
\text { TLR ligands }\end{array}$ & Enhances IL $1 \alpha$ expression & $\begin{array}{l}\text { recruits RNA polymerase II } \\
\text { to the IL1- } \alpha \text { promotor }\end{array}$ & Chan et al., 2015 \\
\hline MEG3 & THP-1 cells & M. bovis BCG & autophagy & Unknown & Pawar et al., 2016a \\
\hline
\end{tabular}


when they were stimulated with TLR4- and TLR2- but not with TLR3-ligands (Cui et al., 2014). By increasing trimethylation of $\mathrm{H} 3 \mathrm{~K} 27$ at the proximal promotor, lnc-IL7R was able to reduce the expression of LPS-induced inflammatory mediators such as E-selectin and VCAM-1. However, the mechanism by which the trimethylation state of H327k was affected could not be elucidated since the authors found no interaction between lncIL7R and members of the PCR 2 complex or other protein binding partners of lnc-IL7R.

In contrast to generating a repressive chromatin state, the lncRNA NeST has been shown to turn chromatin to an active state by binding WDR5 in the Histone 3 Lysine 4 methyltransferase complex (H3K4). The trimethylation of $\mathrm{H} 3 \mathrm{~K} 4$ establishes an active chromatin state at the INF- $\gamma$ locus leading to INF- $\gamma$ accumulation. Initially the lncRNA NeST was linked to Theiler virus susceptibility. Gomez et al. found out that it controls the pathogenesis of another pathogen. They demonstrated that mice expressing NeST RNA show increased susceptibility to Theiler but decreased Salmonella pathogenicity (Gomez et al., 2013). Binding of the adapter protein WDR5 by lncRNAs to generate an active chromatin state at $\mathrm{H} 3 \mathrm{~K} 4$ has been shown for other lncRNAs (e.g., HOTTIP) and might be demonstrated for further lncRNAs in the future.

\section{The Role of NFKB}

As described above, many lncRNAs were reported to interfere with NFкB signaling (Ilott et al., 2014; Ma et al., 2016). NFкB proteins are a family of five structurally related transcription factors controlling the expression of inflammatory molecules to counteract bacterial infection. The process of NFKB activation is mediated via recognition of pathogen-associated-molecular patterns (PAMPS) on the outer side of the microbe through respective pattern-recognition receptors such as TLRs found on the membrane and in the cytoplasm of host cells. To overcome immune response, bacteria have developed mechanism to modulate NFKB signaling (Johannessen et al., 2013).

Interestingly, the expression of several lncRNAs has been linked to TLR-dependent NFKB activation. This suggests that lncRNAs are involved in $\mathrm{NF} \kappa \mathrm{B}$ signaling regulating the transcription of not only cytokines during host response but also regulating several aspects of innate and adaptive immune response such as differentiation, proliferation and survival. An example is lincRNA-Cox2. It has been first reported to be upregulated in mouse bone-marrow-derived dendritic cells after TLR4 stimulation while it was only slightly increased upon TLR3 stimulation. It is located $51 \mathrm{~kb}$ upstream of the Cox 2 coding gene and induced directly via NкFкB (Guttman et al., 2009). Similarly, in another study, lincRNA-Cox2 was among the most highly induced lncRNA candidates in mouse macrophages when stimulated with the TLR2 ligand Pam3CSK4 but also induced by TLR4- and TLR7/8-stimulation as well as L. monocytogenes infection (Carpenter et al., 2013). Although it was shown to form a complex with hnRNP A/B and A2/B1, no direct target of lincRNA-Cox 2 was identified. However, the authors were able to show that lincRNA-Cox 2 both positively and negatively regulated the expression of immune related genes.

The interaction with hnRNPs to influence TLR/NFKB signaling has also been demonstrated for other lncRNAs. The
lncRNA THRIL (TNF- $\alpha$ and hnRNPL related immunoregulatory LincRNA) has been found to be dysregulated in human THP-1 macrophages stimulated with TLR2 ligand. The authors found that THRIL regulates TNF- $\alpha$ expression by interacting with hnRNP-L (Li et al., 2014). THRIL and hnRNP-L possibly form a complex that stimulates TNF- $\alpha$ transcription by binding to the TNF- $\alpha$ promotor. Furthermore, the expression of many other NFKB-dependent pro-inflammatory cytokines were influenced by THRIL, demonstrated through THRIL knockdown. Atianand et al. identified another lncRNA (lincRNA-EPS) that controls $\mathrm{NF} \kappa \mathrm{B}$ dependent immune related genes in TLR-stimulated as well as L. monocytogenes infected macrophages and dendritic cells by binding hnRNPs (Atianand et al., 2016). Besides lincRNA-Cox2 and lincRNA-EPS another lncRNA called ASIL1 $\alpha$ has been shown to be induced after $L$. monocytogenes infection of mouse macrophages as well as stimulation with a range of TLR ligands (Pam3CSK4-TLR2, LPS-TLR4, polyinosinic-polycytidylic acid-TLR3) in a NFKB dependent fashion. AS-IL $1 \alpha$ is partially complementary to IL $1 \alpha$ and has been shown to enhance IL $1 \alpha$ expression by recruiting RNA pol II to the IL1 $\alpha$ promotor (Chan et al., 2015).

The question if lncRNA-interference with NFKB and other immune related pathways favors the host or the pathogen needs to be investigated under defined conditions. The lncRNAs expressed in response to TLR stimulation might belong to a core response to fine tune immune function as described for microRNAs (Siddle et al., 2015). If there are specific lncRNA candidates manipulated by bacterial effector proteins or individual virulence factors needs to be in the focus of further investigations. Interestingly, viable but not heat killed $M$. bovis BCG were able to downregulate the lncRNA MEG3 in macrophages indicating a participation of effectors derived from viable bacteria influencing lncRNA expression (Pawar et al., 2016a).

\section{Interaction with MicroRNAs}

As described in the introduction, there is evolving evidence that lncRNAs and miRNAs influence each other through diverse mechanisms (Yoon et al., 2014). However, until today there is no data confirming this crosstalk in host cells during bacterial infection.

Nevertheless, our group recently identified a participation of the IncRNA MEG3 in the process of autophagy in macrophages infected with $M$. bovis BCG based on the hypothesis that lncRNAs and miRNAs directly interact. Pathway analysis and subsequent follow-up experiments revealed MEG3 to exhibit a regulatory function in autophagy (Pawar et al., 2016a). Although, the exact mechanism and miRNA-interaction partner remains to be elucidated in this case, we presume that diverse functions of lncRNAs involved in bacterial infections are mediated through their interaction with miRNAs.

\section{CONCLUSION/OUTLOOK}

According to the reviewed literature, lncRNAs seem to be important epigenetic regulators of the mammalian immune response toward bacterial infection. However, lncRNA research is still in its infancy compared to research on miRNAs, especially 
regarding their role in bacterial diseases. Not only based on their length but also because of heterogeneous mechanisms and molecular modes of action lncRNAs completely differ from miRNA and are believed to prompt substantial clues in regulation of host response to bacterial infections.

Since miRNAs were first described in 1993, the use of miRNAs as a diagnostic tool but also their therapeutic application for various types of diseases are a major focus of investigation and initial miRNA-based therapeutics are currently examined in clinical trials (Li and Rana, 2014). So far, it appears that the use of lncRNAs as a diagnostic marker and therapeutic agents might be more prosperous since lncRNAs seem to be tissue- and target-specific in contrast to miRNAs which are master-regulators in several tissues and often target multiple mRNAs. This could make lncRNAs more specific biomarkers but also promising therapeutics for a certain disease due to minimized off-target effects. However, a lncRNA exhibiting exclusively pathogenic or beneficial potential during infection has yet not been described. Furthermore, it is still unknown if there are specific lncRNAs expressed in response to a certain pathogen or if lncRNAs are mainly involved in basic cellular immune responses to different stress stimuli. In case of miRNAs it was shown that a core temporal miRNA expression pattern is induced in response to infection, shared across different bacterial species. In addition, pathogen-specific miRNAs were

\section{REFERENCES}

Atianand, M. K., Hu, W., Satpathy, A. T., Shen, Y., Ricci, E. P., AlvarezDominguez, J. R., et al. (2016). A long noncoding RNA lincRNA-EPS acts as a transcriptional Brake to restrain inflammation. Cell 165, 1672-1685. doi: 10.1016/j.cell.2016.05.075

Bertone, P., Stolc, V., Royce, T. E., Rozowsky, J. S., Urban, A. E., Zhu, X., et al. (2004). Global identification of human transcribed sequences with genome tiling arrays. Science 306, 2242-2246. doi: 10.1126/science.1103388

Birney, E., Stamatoyannopoulos, J. A., Dutta, A., Guigo, R., Gingeras, T. R., Margulies, E. H., et al. (2007). Identification and analysis of functional elements in $1 \%$ of the human genome by the ENCODE pilot project. Nature 447, 799-816. doi: 10.1038/nature05874

Carpenter, S., Aiello, D., Atianand, M. K., Ricci, E. P., Gandhi, P., Hall, L. L., et al. (2013). A long noncoding RNA mediates both activation and repression of immune response genes. Science 341, 789-792. doi: 10.1126/science. 1240925

Cech, T. R., and Steitz, J. A. (2014). The noncoding RNA revolution-trashing old rules to forge new ones. Cell 157, 77-94. doi: 10.1016/j.cell.2014.03.008

Chan, J., Atianand, M., Jiang, Z., Carpenter, S., Aiello, D., Elling, R., et al. (2015). Cutting edge: a natural antisense transcript, AS-IL1alpha, controls inducible transcription of the proinflammatory cytokine IL-1alpha. J. Immunol. 195, 1359-1363. doi: 10.4049/jimmunol.1500264

Cui, H., Xie, N., Tan, Z., Banerjee, S., Thannickal, V. J., Abraham, E., et al. (2014). The human long noncoding RNA lnc-IL7R regulates the inflammatory response. Eur. J. Immunol. 44, 2085-2095. doi: 10.1002/eji.201344126

Das, K., Garnica, O., and Dhandayuthapani, S. (2016). Modulation of host miRNAs by intracellular bacterial pathogens. Front. Cell. Infect. Microbiol. 6:79. doi: $10.3389 /$ fcimb. 2016.00079

Eulalio, A., Schulte, L., and Vogel, J. (2012). The mammalian microRNA response to bacterial infections. RNA Biol. 9, 742-750. doi: 10.4161/rna.20018

Gomez, J. A., Wapinski, O. L., Yang, Y. W., Bureau, J. F., Gopinath, S., Monack, D. M., et al. (2013). The NeST long ncRNA controls microbial susceptibility and epigenetic activation of the interferon-gamma locus. Cell 152, 743-754. doi: $10.1016 /$ j.cell.2013.01.015 identified reflecting the mechanism by which certain pathogens interfere with the host response to infection (Siddle et al., 2015). Studies comparing the lncRNA expression in response to different pathogens possessing different virulence mechanisms are missing. However, it was shown that two strains of $M$. tuberculosis that differ in virulence induced distinct lncRNA expression profiles (Yang X. et al., 2016). Regarding the therapeutic application, lncRNAs are interesting candidates for host-directed therapies which is a new evolving concept to treat bacterial infections such as tuberculosis. Targeting the host rather than the pathogen prevents development of antibiotic resistance and supports immune defense mechanisms during infection (Zumla et al., 2016). Influencing the expression of lncRNAs that augment cellular antimicrobial mechanisms such as autophagy or directly reducing inflammation is therefore a promising approach, especially to treat multi-drug-resistant infections.

Finally, there is still a long journey ahead to identify and elucidate cellular functions and mechanisms of lncRNAs regulated by bacterial pathogens.

\section{AUTHOR CONTRIBUTIONS}

JZ and SS literature research, wrote manuscript; RE: wrote manuscript.
Guttman, M., Amit, I., Garber, M., French, C., Lin, M. F., Feldser, D., et al. (2009). Chromatin signature reveals over a thousand highly conserved large non-coding RNAs in mammals. Nature 458, 223-227. doi: 10.1038/nature 07672

Hanisch, C., Sharbati, J., Kutz-Lohroff, B., Huber, O., Einspanier, R., and Sharbati, S. (2017). TFF3-dependent resistance of human colorectal adenocarcinoma cells HT-29/B6 to apoptosis is mediated by miR-491-5p regulation of lncRNA PRINS. Cell Death Discov. 3:16106. doi: 10.1038/cddiscovery.2016.106

Heward, J. A., and Lindsay, M. A. (2014). Long non-coding RNAs in the regulation of the immune response. Trends Immunol. 35, 408-419. doi: 10.1016/j.it.2014.07.005

Hoeke, L., Sharbati, J., Pawar, K., Keller, A., Einspanier, R., and Sharbati, S. (2013). Intestinal Salmonella typhimurium infection leads to miR-29a induced caveolin 2 regulation. PLoS ONE 8:e67300. doi: 10.1371/journal.pone.0067300

Ilott, N., Heward, J. A., Roux, B., Tsitsiou, E., Fenwick, P. S., Lenzi, L., et al. (2014). Long non-coding RNAs and enhancer RNAs regulate the lipopolysaccharideinduced inflammatory response in human monocytes. Nat. Commun. 5:3979. doi: $10.1038 /$ ncomms 4979

Johannessen, M., Askarian, F., Sangvik, M., and Sollid, J. E. (2013). Bacterial interference with canonical NFאB signalling. Microbiology 159(Pt 10), 2001-2013. doi: 10.1099/mic.0.069369-0

Kaakoush, N. O., Deshpande, N. P., Man, S. M., Burgos-Portugal, J. A., Khattak, F. A., Raftery, M. J., et al. (2015). Transcriptomic and proteomic analyses reveal key innate immune signatures in the host response to the gastrointestinal pathogen Campylobacter concisus. Infect. Immun. 83, 832-845. doi: 10.1128/IAI.03012-14

Khalil, A. M., Guttman, M., Huarte, M., Garber, M., Raj, A., Rivea Morales, D., et al. (2009). Many human large intergenic noncoding RNAs associate with chromatin-modifying complexes and affect gene expression. Proc. Natl. Acad. Sci. U.S.A. 106, 11667-11672. doi: 10.1073/pnas.0904715106

Kim, J. K., Kim, T. S., Basu, J., and Jo, E. K. (2017). MicroRNA in innate immunity and autophagy during mycobacterial infection. Cell Microbiol. 19:e12687. doi: $10.1111 / \mathrm{cmi} .12687$

Kurtz, S., McKinnon, K. P., Runge, M. S., Ting, J. P., and Braunstein, M. (2006). The SecA2 secretion factor of Mycobacterium tuberculosis promotes growth 
in macrophages and inhibits the host immune response. Infect. Immun. 74, 6855-6864. doi: 10.1128/IAI.01022-06

Li, Z., and Rana, T. M. (2014). Therapeutic targeting of microRNAs: current status and future challenges. Nat. Rev. Drug Discov. 13, 622-638. doi: 10.1038/nrd4359

Li, Z., Chao, T. C., Chang, K. Y., Lin, N., Patil, V. S., Shimizu, C., et al. (2014). The long noncoding RNA THRIL regulates TNFalpha expression through its interaction with hnRNPL. Proc. Natl. Acad. Sci. U.S.A. 111, 1002-1007. doi: 10.1073/pnas.1313768111

Ma, S., Ming, Z., Gong, A. Y., Wang, Y., Chen, X., Hu, G., et al. (2016). A long noncoding RNA, lincRNA-Tnfaip3, acts as a coregulator of NF- $\kappa B$ to modulate inflammatory gene transcription in mouse macrophages. FASEB J. 31, 1215-1225. doi: 10.1096/fj.201601056R

Mao, A. P., Shen, J., and Zuo, Z. (2015). Expression and regulation of long noncoding RNAs in TLR4 signaling in mouse macrophages. BMC Genomics 16:45. doi: 10.1186/s12864-015-1270-5

Marques, A. C., and Ponting, C. P. (2009). Catalogues of mammalian long noncoding RNAs: modest conservation and incompleteness. Genome Biol. 10:R124. doi: 10.1186/gb-2009-10-11-r124

Pang, K. C., Frith, M. C., and Mattick, J. S. (2006). Rapid evolution of noncoding RNAs: lack of conservation does not mean lack of function. Trends Genet. 22, 1-5. doi: 10.1016/j.tig.2005.10.003

Pawar, K., Hanisch, C., Palma Vera, S. E., Einspanier, R., and Sharbati, S. (2016a). Down regulated lncRNA MEG3 eliminates mycobacteria in macrophages via autophagy. Sci. Rep. 6:19416. doi: 10.1038/srep19416

Pawar, K., Sharbati, J., Einspanier, R., and Sharbati, S. (2016b). Mycobacterium bovis BCG interferes with miR-3619-5p control of cathepsin S in the process of autophagy. Front. Cell. Infect. Microbiol. 6:27. doi: 10.3389/fcimb.2016.00027

Pieters, J. (2008). Mycobacterium tuberculosis and the macrophage: maintaining a balance. Cell Host Microbe 3, 399-407. doi: 10.1016/j.chom.2008.05.006

Rahman, M. M., and McFadden, G. (2006). Modulation of tumor necrosis factor by microbial pathogens. PLoS Pathog. 2:e4. doi: 10.1371/journal.ppat.0020004

Reed, M. B., Domenech, P., Manca, C., Su, H., Barczak, A. K., Kreiswirth, B. N., et al. (2004). A glycolipid of hypervirulent tuberculosis strains that inhibits the innate immune response. Nature 431, 84-87. doi: 10.1038/nature02837

Rinn, J. L. (2014). lncRNAs: linking RNA to chromatin. Cold Spring Harb. Perspect. Biol. 6:a018614. doi: 10.1101/cshperspect.a018614

Rocco, J. M., and Irani, V. R. (2011). Mycobacterium avium and modulation of the host macrophage immune mechanisms. Int. J. Tuberc. Lung Dis. 15, 447-452. doi: 10.5588/ijtld.09.0695

Rodriguez, A., Vigorito, E., Clare, S., Warren, M. V., Couttet, P., Soond, D. R., et al. (2007). Requirement of bic/microRNA-155 for normal immune function. Science 316, 608-611. doi: 10.1126/science.1139253

Salmena, L., Poliseno, L., Tay, Y., Kats, L., and Pandolfi, P. P. (2011). A ceRNA hypothesis: the Rosetta Stone of a hidden RNA language? Cell 146, 353-358. doi: 10.1016/j.cell.2011.07.014

Schulte, L. N., Eulalio, A., Mollenkopf, H. J., Reinhardt, R., and Vogel, J. (2011). Analysis of the host microRNA response to Salmonella uncovers the control of major cytokines by the let-7 family. EMBO J. 30, 1977-1989 doi: 10.1038/emboj.2011.94

Sharbati, J., Lewin, A., Kutz-Lohroff, B., Kamal, E., Einspanier, R., and Sharbati, S. (2011). Integrated microRNA-mRNA-analysis of human monocyte derived macrophages upon Mycobacterium avium subsp. hominissuis infection. PLoS ONE 6:e20258. doi: 10.1371/journal.pone.0020258

Sharbati, S., Sharbati, J., Hoeke, L., Bohmer, M., and Einspanier, R. (2012). Quantification and accurate normalisation of small RNAs through new custom RT-qPCR arrays demonstrates Salmonella-induced microRNAs in human monocytes. BMC Genomics 13:23. doi: 10.1186/1471-2164-13-23

Shi, L., Song, L., Fitzgerald, M., Maurer, K., Bagashev, A., and Sullivan, K. E. (2014). Noncoding RNAs and LRRFIP1 regulate TNF expression. J. Immunol. 192, 3057-3067. doi: 10.4049/jimmunol.1302063

Siddle, K. J., Tailleux, L., Deschamps, M., Loh, Y. H., Deluen, C., Gicquel, B., et al. (2015). Bacterial infection drives the expression dynamics of microRNAs and their isomiRs. PLoS Genet. 11:e1005064. doi: 10.1371/journal.pgen.1005064
Singh, Y., Kaul, V., Mehra, A., Chatterjee, S., Tousif, S., Dwivedi, V. P., et al. (2013). Mycobacterium tuberculosis controls microRNA-99b (miR-99b) expression in infected murine dendritic cells to modulate host immunity. J. Biol. Chem. 288, 5056-5061. doi: 10.1074/jbc.C112.439778

Song, H. Y., Rothe, M., and Goeddel, D. V. (1996). The tumor necrosis factorinducible zinc finger protein A20 interacts with TRAF1/TRAF2 and inhibits NF-кB activation. Proc. Natl. Acad. Sci. U.S.A. 93, 6721-6725.

St Laurent, G., Wahlestedt, C., and Kapranov, P. (2015). The landscape of long noncoding RNA classification. Trends Genet. 31, 239-251. doi: 10.1016/j.tig.2015.03.007

Wang, K. C., and Chang, H. Y. (2011). Molecular mechanisms of long noncoding RNAs. Mol. Cell 43, 904-914. doi: 10.1016/j.molcel.2011.08.018

Wang, K. C., Yang, Y. W., Liu, B., Sanyal, A., Corces-Zimmerman, R., Chen, Y., et al. (2011). A long noncoding RNA maintains active chromatin to coordinate homeotic gene expression. Nature 472, 120-124. doi: 10.1038/nature09819

Wang, Y., Zhong, H., Xie, X., Chen, C. Y., Huang, D., Shen, L., et al. (2015). Long noncoding RNA derived from CD244 signaling epigenetically controls CD8+ T-cell immune responses in tuberculosis infection. Proc. Natl. Acad. Sci. U.S.A. 112, E3883-E3892. doi: 10.1073/pnas.1501662112

Westermann, A. J., Forstner, K. U., Amman, F., Barquist, L., Chao, Y., Schulte, L. N., et al. (2016). Dual RNA-seq unveils noncoding RNA functions in host-pathogen interactions. Nature 529, 496-501. doi: 10.1038/nature16547

Yang, L., Long, Y., Li, C., Cao, L., Gan, H., Huang, K., et al. (2015). Genome-wide analysis of long noncoding RNA profile in human gastric epithelial cell response to Helicobacter pylori. Jpn. J. Infect. Dis. 68, 63-66. doi: 10.7883/yoken.JJID.2014.149

Yang, R., Huang, F., Fu, J., Dou, B., Xu, B., Miao, L., et al. (2016). Differential transcription profiles of long non-coding RNAs in primary human brain microvascular endothelial cells in response to meningitic Escherichia coli. Sci. Rep. 6:38903. doi: 10.1038/srep38903

Yang, X., Yang, J., Wang, J., Wen, Q., Wang, H., He, J., et al. (2016). Microarray analysis of long noncoding RNA and mRNA expression profiles in human macrophages infected with Mycobacterium tuberculosis. Sci. Rep. 6:38963. doi: 10.1038/srep38963

Yi, Z., Li, J., Gao, K., and Fu, Y. (2014). Identifcation of differentially expressed long non-coding RNAs in CD4+ T cells response to latent tuberculosis infection. J. Infect. 69, 558-568. doi: 10.1016/j.jinf.2014.06.016

Yoon, J. H., Abdelmohsen, K., and Gorospe, M. (2014). Functional interactions among microRNAs and long noncoding RNAs. Semin. Cell Dev. Biol. 34, 9-14. doi: 10.1016/j.semcdb.2014.05.015

Zhu, H., Wang, Q., Yao, Y., Fang, J., Sun, F., Ni, Y., et al. (2015). Microarray analysis of long non-coding RNA expression profiles in human gastric cells and tissues with Helicobacter pylori Infection. BMC Med. Genomics 8:84. doi: 10.1186/s12920-015-0159-0

Zumla, A., Rao, M., Wallis, R. S., Kaufmann, S. H., Rustomjee, R., Mwaba, P., et al. (2016). Host-directed therapies for infectious diseases: current status, recent progress, and future prospects. Lancet Infect. Dis. 16, e47-e63. doi: 10.1016/S1473-3099(16)00078-5

zur Bruegge, J., Backes, C., Gölz, G., Hemmrich-Stanisak, G., Scharek-Tedin, L., Franke, A., et al. (2016). MicroRNA response of primary human macrophages to Arcobacter butzleri infection. Eur. J. Microbiol. Immunol. 6, 99-108. doi: 10.1556/1886.2016.00015

Conflict of Interest Statement: The authors declare that the research was conducted in the absence of any commercial or financial relationships that could be construed as a potential conflict of interest.

Copyright (C) 2017 zur Bruegge, Einspanier and Sharbati. This is an open-access article distributed under the terms of the Creative Commons Attribution License (CC BY). The use, distribution or reproduction in other forums is permitted, provided the original author(s) or licensor are credited and that the original publication in this journal is cited, in accordance with accepted academic practice. No use, distribution or reproduction is permitted which does not comply with these terms. 